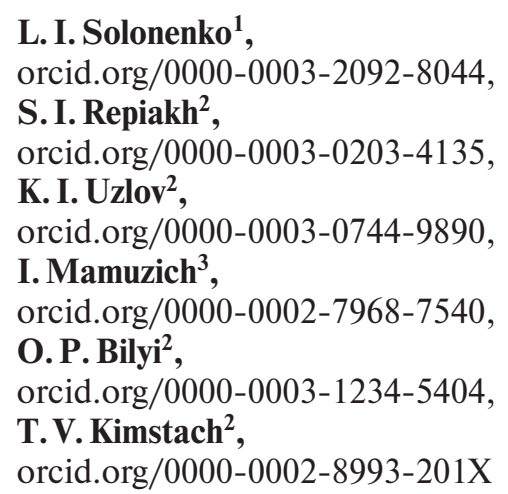

1 - Odesa Polytechnic State University, Odesa, Ukraine

2 - National Metallurgical Academy of Ukraine, Dnipro, Ukraine, e-mail: 123rs@ua.fm

3 - University of Zagreb, Croatian Metallurgical Society, Zagreb, the Republic of Croatia

\title{
WATER RESISTANCE OF STRUCTURED SAND-SODIUM-SILICATE MIXTURES
}

Purpose. To establish regularities of changes in sand-sodium-silicate mixtures (SSSM) relative water resistance, structured by steam-microwave solidification method (SMS), on their structuring parameters and sodium silicate solute (SSS) dissolution conditions.

Methodology. Technical purity water, SSS with 2.8-3.0 silicate modulus, quartz sand with $0.23 \mathrm{~mm}$ average particle size were used in this work. Studies were carried out on quartz sand samples, which were preliminarily cladded with $0.5-2.5 \%$ (by weight) SSS and structured by SMS method. The fracture time of structured mixtures was evaluated on cubic specimens with $20 \mathrm{~mm}$ rib length, which were immersed in water at different temperatures.

Findings. Changes in SSSM water resistance in water regularities depending on their manufacturing, use and storage conditions were established. Recommendations for SSSM rods removal from castings in water were developed.

Originality. For the first time, it has been established that relative water resistance of the SSSM structured by SMS method decreases along with increase in water temperature in which it is destroyed. Depending on SSS mass used for quartz sand cladding in range $0.5-2.5 \%$, water resistance dependence on treatment in steam-microwave environment with $2-7$ minutes' running time acquires an inversion character with inversion point $\sim 3.1$ minutes into the processing.

For the first time, it has been discovered that in boiling water the relative water resistance of SSSM, structured by SMS-process and having preheating, monotonically increases with preheating temperature rising from 100 to $600{ }^{\circ} \mathrm{C}$, sharply increases when heated to $600-700{ }^{\circ} \mathrm{C}$ and practically becomes absolute after preliminarily preheating to higher temperatures.

Practical value. Research results will be useful in concepts of processes accompanying destruction of structured sands with water-soluble binders expanding, as well as in technologies and equipment development designed for SSS rods and mold rests removing from castings.

Keywords: water resistance, sodium silicate solute, sand-sodium-silicate mixture, knockout, steam-microwave solidification, rod

Introduction. Aqueous sodium silicates solutions - sodium silicate solute (SSS) are used as binder (glue), as detergent component $[1,2]$, in production of thermal insulation materials and paper [3], concrete [4], paints [5], for strengthening soils and wells in construction and mining industries [6], and so on. Sodium silicate solute is also used in foundry for casting molds and rods, refractory paints and linings manufacturing [7].

Cast products are integral part of almost any product for industrial or household use. Therefore, steady increasing in economy, efficiency and environmental safety of cast parts production have been and remain the main problems that are constantly being solved by foundry engineers.

In casting production, the most environmentally and sanitary-hygienically dangerous periods of technology are the melting period and also, in case of using organic origin binder material in molding mixture or disposable model from gasified material, periods of melt pouring into the mold, solidification and casting chill in the mold. Under certain industrial conditions, as well as in case of using inorganic origin binder, such emerging dangerous from the side of casting molds and cores (CMC) can be practically reduced to zero. That is, among the most environmentally and sanitary-hygienically dangerous procedures are casting production according to gasified (expanded polystyrene) models, casting into molding and core mixtures, in which synthetic resin, oil, lignosulfonate, and others are used as binder material, as well as phosphoric acid and its salts. At the same time, CMCs, in which water, clay, siliceous, as well as sodium silicate water solution (sodium silicate solute - SSS) are used as

(C) Solonenko L. I., Repiakh S. I., Uzlov K. I., Mamuzich I., Bilyi O. P., Kimstach T. V., 2021 binding materials, are environmentally and sanitary-hygienically safe. Currently, in foundries, share of SSS used in CMC production is not large. This is mainly due to the high energy consumption and, in some cases, impossibility of sand-sodium-silicate mixtures (SSSM) removing from castings [8, 9]. Therefore, most of foundries for CMC manufacturing use synthetic resins, which, with all their environmental and economic disadvantages, make it possible to obtain CMC with a higher level of technological properties. Using resin in CMC is accompanied by a large amount of carcinogenic and toxic gaseous substances (formaldehyde, phenol, benzene, and so on) polluting into foundries working areas and, accordingly, into the environment. At the same time, release of such substances into air begins from the moment of CMC manufacturing, increases sharply from the moment of pouring to the moment of knocking out the casting from mold and rod and does not finish even after disposing spent mixture in dumps [10].

To solve this environmental problem, instead of organic origin binding materials, a number of authors now recommend returning to use inorganic binding materials, in particular, to phosphate binders, including aluminum-chromium phosphate, aluminum-iron phosphate [11], aluminum-boron phosphate concentrate with powder-solidifier based on magnesium oxide [12], phosphoric acid with chemically active dust addition to CMC [13], and so on or SSS. Possessing obvious environmental advantages over organic binders, phosphatesand mixtures, however, are characterized by unstable properties and acidic properties undesirable for use, regeneration and disposal of waste mixtures. Sand, clay and water mixtures are structured in conductors by cooling them down to $-15--75^{\circ} \mathrm{C}$. This creates danger of frostbite for molders and requires expen- 
sive refrigeration equipment. Mixtures with gypsum and cement also have a number of their own characteristics and conditions of implementation, are characterized by significant dust emission during their preparation and knocking out castings from them, as well as laboriousness of regeneration. That is, from this point of view SSSM is more promising.

SSSM structuring is carried out after their manual or mechanical compaction in equipment by heat drying (dehydration), blowing with carbon dioxide, due to adding powdered dicalcium silicate, complex ether, and so on to the mixture. The main disadvantages of such mixtures are major efforts of castings mechanical knocking out and/or sand regeneration laboriousness. In this regard, wasted SSSMs are disposed without regeneration at landfills, in dumps, are partially used in road construction, and so on.

Summarizing results of numerous publications and studies, Lucarz M. (2008) in his works notes that disposal of waste CMC in dumps or its use in road construction, to fill closed mines cavities, etc. poses critical threat for environmental safety. Therefore, waste quartz sand regeneration is a mandatory technological operation that should be performed not only for its recycling, but also in terms of its subsequent safe disposal.

In order to facilitate SSSM knocking out from castings, it is proposed to add certain technological additives to SSS, modify SSS during its preparation, reduce SSS content in mixture, and so on [7, 8, etc.]. At the same time, the authors of these works consider SSSM removal from castings solely from viewpoint of shock and vibration effects on them.

In accordance with data [14], SSSM knocking out work (A) depends on method for its structuring, heating temperature and can be described by dependencies whose characteristic forms are presented in Fig. 1.

According to authors [14, 15] (Fig. 1), maximum upon SSSM heating to $200{ }^{\circ} \mathrm{C}$ is consequence of sodium silicate and $\mathrm{SiO}_{2}$ gel mixture in cuffs formation. SSSM heating to $600{ }^{\circ} \mathrm{C}$ leads to de-strengthening and gel destruction as a result of SSSM thermal expansion. When heated to $800{ }^{\circ} \mathrm{C}$, SSSM knocking out work increases again, which is due to sodium silicate melting, formation of more perfect-shaped cuffs and their solidification upon subsequent cooling. Mixtures heating to $900-1100^{\circ} \mathrm{C}$ and their subsequent cooling are accompanied by partial silicon dioxide dissolution from sand grains in molten sodium silicate and its subsequent devitrification (partial crystallization), which leads to SSSM knocking out work decreasing, when heated to these temperatures.

To reduce knocking out work, many scientists and researchers recommend reducing water glass content in mixture to $2-3 \%$ (by mass), using technological additives in SSSM (carbon-containing materials, metallurgical dust, sulphite waste liquor, wood and cardboard dust, iron sulfate hydrate, kaolin, and others). Authors [8] recommend using exclusively pore-forming or thermally expanding materials as such additives for SSSM.

A large number and variety of recommended technological aids in SSSM are mainly due to:

- peculiarity of SSS and sodium silicate physicochemical properties;

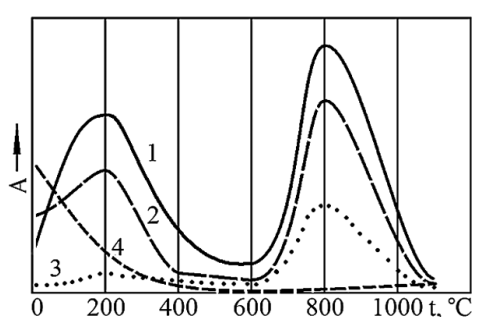

Fig. 1. Type of generalized dependences of SSSM knocking out (A) work structured with:

1 - complex ether; 2 - carbon dioxide; 3 - dicalcium silicate; 4 microwave heating on their preheating temperature
- technological limitations and peculiarities of using technological additives;

- instability of properties and efficiency of technological additives from natural and technogenic origin materials;

- expensiveness of industrially produced technological additives.

The disadvantages of using any technological additives include:

- necessity of energy-intensive sand regeneration for its recycling;

- lack of comprehensive solution to problems of low manufacturability, inherent in sand-sodium-silicate CMC.

That is, no technological additive in SSSM will fully provide a required level of processability for mixtures and CMC made from them.

SSSM structuring by SMS-process is one of ways of comprehensive solution to this problem. Since when used in mixture of less than 2-3\% (by weight) SSS without any technological additives in SMS provides opportunities of:

- filling the rigging with mixture by free pouring and vibration compaction;

- fast mixture in rigging structuring (solidifying);

- exclusion of CMC drying process;

- process of knocking out castings from castings molds and cores low energy consumption;

- multiply reusing of waste mixture after grinding and sieving in $\mathrm{CMC}$ production;

- elimination of necessity for regeneration and disposal of spent mixture due to its use as raw material for subsequent silicate block production.

Unlike dependences 1-3 in Fig. 1, dependence 4 has no maxima and testifies to the low value of SSSM structured by microwave radiation knocking out work when it is heated to temperatures above $300^{\circ} \mathrm{C}$. M. Stachowicz, K. Granat, D. Nowak (2011) see such difference in nature of course dependences in Fig. 1 in structure peculiarities of sodium silicate cuffs between sand grains, which are formed under microwave radiation on the mixture action.

Depending on mass ratio, wall sizes, pouring conditions, melt poured into the mold temperature and a number of other parameters, the temperature of the rod's various parts can vary from the initial rod temperature before melt pouring into the mold moment to the liquidus temperature of alloy poured into the mold. Based on this, a number of areas can be distinguished in sand-sodium-silicate rods, whose diagrams are shown in Figs. 2, $a-f$, and character of temperature distribution over the cross section of the rod for corresponding schemes is shown in Fig. 2, $e$.

If it is assumed that temperature td is heating temperature at which subsequently cooled sodium silicate in cuffs of structured mixture loses its ability to dissolve in water within technologically acceptable time, then it follows that sand-sodiumsilicate rods structured as result of sodium silicate dehydration, under certain conditions, can be completely (Fig. 2, $a$ ) or partially (Fig. 2, b) removed from castings not only by shockvibration action on castings, but also as a result of their contact with water. In all other cases (Figs. 2, $c-f$ ), rods removal should be carried out by shock-vibration action on castings.

Ability to remove rods by immersing them in water is important not only for castings from alloys with low hardness (alloys based on copper, aluminum, zinc, lead, and others), but also with low ductility (cast iron), etc. Nevertheless, until now, there are no data on possibility of removing sand-sodium-silicate rods structured in steam-microwave environment from castings. This reduces commercial attractiveness of this method for producing rods and does not contribute to solving the problem of lowering energy consumption of technological operation of knocking out sand-sodium-silicate rods from castings, generally.

In this regard, search for new technical solutions to reduce energy consumption of technological operation of knocking out sand-sodium-silicate rods from castings, in particular, by 


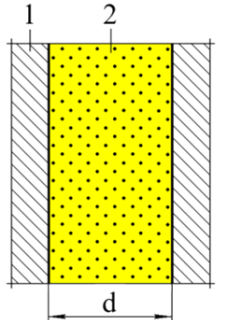

$a$

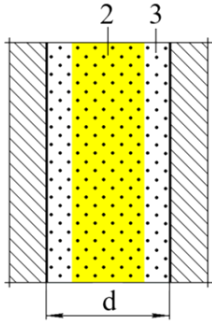

$b$

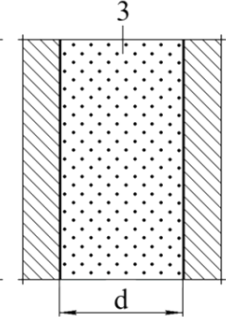

$c$

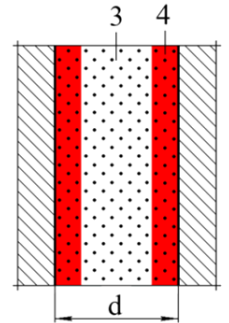

$d$

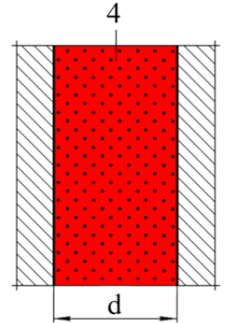

$e$

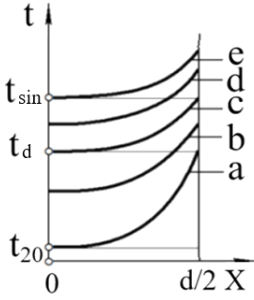

$f$

Fig. 2. Diagram of rod areas in section after temperature reaching on its surface $\left(t_{s}\right)$ and in axial part $\left(t_{a}\right)$, in which: sodium silicate dissolution temperature $\left(t_{d}\right)$ is $t_{d}>t_{s}>t_{a}(a)$, sodium silicate sintering temperature $\left(\mathrm{t}_{\sin }\right)$ in mixture cuffs is $t_{\text {sin }}>t_{s}>t_{d}>t_{a}(b)$, $t_{\text {sin }}>$ $>t_{s}>t_{a}>t_{d}(c), t_{s}>t_{\sin }>t_{a}>t_{d}(d), t_{s}>t_{a}>t_{\sin }(f)$ and temperature distribution over rods cross section (e) for cases a- $f$ : 1 - casting; 2 - rod area removed in water; 3 - rod area removed as a result of light shock and vibration effect on casting; 4 - rod area that is removed by significant impact on casting or not removed generally

processing them in water, is an urgent problem of scientific and applied importance.

Literature review. SSS specificity as a binder material is its solidification possibility, both as a dehydration result [15] and as a result of chemical reactions leading to sharp increase in its silicate modulus $[16,17]$. It follows from this that sand-sodiumsilicate rods, structured by their dehydration, under certain conditions, can be removed as a result of their immersion in water.

According to V. I. Korneev, V.V. Danilov (1996) SSS with silicate modulus of $2.8-3.0$ is sodium silicate water solution, which, in addition to oligomers, contains silica with high degree of polymerization and high cohesion. That is, it is characterized by certain ratio of molecular (monomeric $-\alpha-\mathrm{SiO}_{2}$ ) and colloidal $\left(\beta-\mathrm{SiO}_{2}\right)$ silica. At the same time, presence of sodium dioxides in dry SSS provides not only its dissolution possibility in water, but also control of this process rate.

According to Waldes H.H. and Lange K. R. (1969), dissolution rate of solid SSS particles in water increases with SSS silicate modulus decreasing, with water temperature increasing, with presence of hydrated water ( $18.5 \%$ by weight) in dry SSS, with dissolved SSS particle size decreasing. Presence of hydrated water in sodium silicate molecules composition is fundamental condition for its rapid dissolution in water [18]. Thus, it will be assumed that loss of SSS solubility occurs with its complete dehydration. Complete dehydration of SSS, according to V. I. Korneev and V. V. Danilov (1996), occurs when SSS reaches $600{ }^{\circ} \mathrm{C}$. Then, SSS should not dissolve in structured SSSM, even briefly heated to temperatures above $600{ }^{\circ} \mathrm{C}$. Accordingly, sand-sodium-silicate rods structured by SSS dehydration and not heated to more than $600{ }^{\circ} \mathrm{C}$ should be removed from castings as a result of their immersion in water.

Korneev V.I. and Danilov V.V.'s (1996) research results showed that SSS dissolution rate can be significantly influenced by surface carbonization of SSS particles dissolved in water. Carbonation is a process whose activity increases after SSS loses its free water and continues until moment when hydration water from sodium silicate removes completely [19]. That is, gradual loss of hydrated water by amorphous silicate solutions with silicate modulus of about 3 , solidified in air, is accompanied by carbon dioxide SSS absorption from air and by appearance of chemical compounds $\mathrm{NaHCO}_{3}, \mathrm{Na}_{2} \mathrm{CO}_{3}$. This process leads not only to sodium ions migration from deep regions to particles surface and crystalline carbonate structures appearance, but also to low-water silica framework formation, as a result [20]. Such framework appearance increases system under consideration water resistance and, therefore, decreases solid SSS particles in water dissolution rate. It follows from this that increase in duration of rods holding in air should lead to their water resistance and, accordingly, increasing duration of removal of rods from castings in water.

It follows from above that water resistance of SSSM structured by dehydration depends on a large number of factors, including method of their solidification. At present, there are no data on SSSM structured in steam-microwave environment (method of steam-microwave solidification - SMS) water resistance and effect of structuring conditions on their water resistance.

Methods. Technical purity water, sodium silicate solute with silicate modulus of 2.8-3.0 and specific density of $1.44 \mathrm{~g} / \mathrm{cm}^{3}$, quartz sand with an average particle size of $0.23 \mathrm{~mm}$ and clay content of up to $0.2 \%$ (by mass) were used in this work.

Mass was determined on electronic balance with an accuracy of $1.0,0.1$ and $0.01 \mathrm{~g}$. Dimensions were measured with Vernier caliper with an accuracy of $0.1 \mathrm{~mm}$. Time was recorded with stopwatch with an accuracy of $1 \mathrm{~s}$.

Studies were carried out on cubic specimens with rib length of $20 \mathrm{~mm}$. Test samples were obtained by cutting blank weighing $2.2 \mathrm{~kg}$ from mixture structured by SMS-process. For blank, quartz sand cladded with sodium silicate solute $0.5-$ $2.5 \%$ (over $100 \%$ sand) was used. Cladded sand was dried in air to water mass content in sodium silicate of $17-19 \%$. After air drying, sand was dried additionally for 5 minutes in microwave furnace with magnetron power of $900 \mathrm{~W}$ and radiation frequency of $2.45 \mathrm{GHz}$.

Cladded sand structuring was carried out after sifting it through a sieve with mesh side of $0.4 \mathrm{~mm}$. For structuring, water portion weighing 1g (water charge - WC) was used, which was placed in foam-polyurethane sponge with dimensions of $\varnothing 30 \times 8 \mathrm{~mm}$. That is, for structuring, foam-polyurethane sponge filled with $1 \mathrm{~g}$ of water was placed on the bottom of a polypropylene box. The box was filled with $2.2 \mathrm{~kg}$ of cladded sand and compacted for 30 minutes by vibration with oscillation frequency of $50 \mathrm{~Hz}$ and amplitude of $1 \mathrm{~mm}$. After compacting, the box was placed in working space of microwave furnace in the center of a rotating table. While furnace table was rotating at frequency of $2.5 \mathrm{rpm}$, the box content was treated with microwave radiation for 8 minutes.

To determine destruction duration, testing specimens were installed on X-type support-bracket and in this state have been immersed in water at appropriate temperature. The scheme for cutting cubes from blank samples and the scheme for cube placing in X-type support-bracket are shown in Fig. 3.

Storage of samples before testing was carried out in open air with relative humidity of $60-62 \%$ at temperature of 20 $26{ }^{\circ} \mathrm{C}$. Destruction of testing samples was carried out in water with temperature during tests which was maintained at a given value (t) with an accuracy of $\pm 1{ }^{\circ} \mathrm{C}$. Ratio of water mass to tested sample mass in it in all cases was $\sim 100$. For sample destruction duration in water, time of its complete removal from $\mathrm{X}$-type support-bracket was taken.

Samples were preheated to specified temperatures in laboratory resistance muffle furnace according to the following regime:

- rate of temperature rise in furnace working space -80 $170^{\circ} \mathrm{C} / \mathrm{h}$

- isothermal holding duration at given temperature $40 \pm 1$ minutes; 


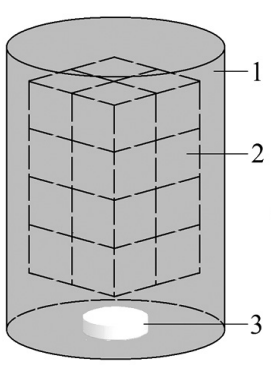

$a$

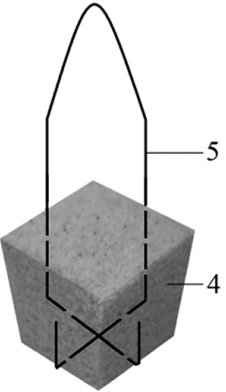

Fig. 3. Scheme of cutting out cubes from samples (a) and placing them in X-type support-bracket $(b)$ :

1 - sample of mixture structured according to SMS-process; 2 cutting planes contours of samples in cubes manufacturing process; 3 - water charge (WC) in sample body (foam-polyurethane saturated with water); 4 - cubic form sample (cube); 5 -X-type support-bracket

- cooling in air outside the furnace from predetermined temperature until the sample reaches $20-22^{\circ} \mathrm{C}$.

Error in temperature determining during samples isothermal holding was less than $3{ }^{\circ} \mathrm{C}$.

Dependence of hydrated water content in structured SSSM sodium silicate cuffs (WC weight during SSSM structuring was $0.5 \mathrm{~g}$ ) was estimated from results of SSSM samples with mass $200-230 \mathrm{~g}$ weighing, heated in microwave furnace for given time. At the same time, duration of steam-microwave treatment $(\mathrm{t})$ was taken into account, with SSS mass used for cladding quartz sand of 0.5 and $2.5 \%$ (over $100 \%$ of the sand). Hydrated water mass in sodium silicate SSSM after microwave treatment was determined by the sample treated with microwave radiation weighing before and after heating it to $700{ }^{\circ} \mathrm{C}$ in resistance furnace, with following it recalculation to dehydrated sodium silicate mass in test sample.

Results. In accordance with research methodology, relative duration value of samples destruction in water (water resistance) was calculated by formula

$$
\nabla=\tau_{i} / \tau_{1},
$$

where $\tau_{i}$ is destruction duration of the $i^{\text {th }}$ sample in water, $\mathrm{s} ; \tau_{1}$ is destruction duration of samples in water (water temperature $80{ }^{\circ} \mathrm{C}$ ) from quartz sand structured by microwave radiation for 2 minutes $\left(\tau_{1}=94 \mathrm{~s}\right)$, cladded with $0.5 \%$ (by mass) SSS.

Dependence of relative duration destruction in boiling water (water resistance) of samples with $1.5 \% \mathrm{SSS}$, structured by SMS-process for 2, 4, and 7 minutes, on their temperature preheating is shown in Fig. 4.

From analysis of dependence course in Fig. 4 it follows that with preheating temperature increasing from 100 to $600{ }^{\circ} \mathrm{C}$, relative duration of samples destruction (water resistance) monotonically increases and can be calculated by formula

$$
\nabla=1.32 \cdot \ln (t)-5.69,
$$

where $t$ is sample preheating temperature from 100 to $600{ }^{\circ} \mathrm{C}$.

In preliminary samples heating from 600 to $700^{\circ} \mathrm{C}$ case, relative duration of their dissolution (water resistance) increases sharply and when heated to temperatures above $700{ }^{\circ} \mathrm{C}$, samples under considered conditions acquire almost absolute water resistance. In this case, relative duration of samples destruction practically does not depend on their structuring duration according to SMS-process within processing range from 2 to 7 minutes.

This dependence of relative duration of samples destruction on their preheating temperature in range from 600 to $700{ }^{\circ} \mathrm{C}$ is explained by dehydration completion and structure of sodium silicate in cuffs between sand grains changing.

This conclusion is confirmed by Korneev V.I. and Danilov V. V.'s data (1996), according to which, after heating sodium

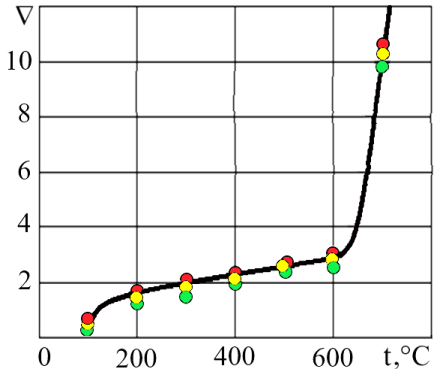

Fig. 4. Dependence of relative duration of destruction of samples structured according to SMS-process in boiling water (water resistance) on their preheating temperature in air (samples exposure time in air at room temperature before testing - 3-4 hours)

tri-silicate to $600{ }^{\circ} \mathrm{C}$ and its subsequent cooling to room temperature sodium tri-silicate exists in form $\beta \mathrm{Na}_{2} \mathrm{O} \cdot 2 \mathrm{SiO}_{2}+$ $+\mathrm{SiO}_{2}$, which contains hydroxyl groups. Apparently, exactly this circumstance is the reason for relatively rapid dissolution of $\beta \mathrm{Na}_{2} \mathrm{O} \cdot 2 \mathrm{SiO}_{2}+\mathrm{SiO}_{2}$ in water (low water resistance). Upon reaching $600^{\circ} \mathrm{C}$, tri-silicate is almost completely dehydrated and loses its ability to rapidly dissolve in water. At temperatures above $665^{\circ} \mathrm{C} \beta \mathrm{Na}_{2} \mathrm{O} \cdot 2 \mathrm{SiO}_{2}+\mathrm{SiO}_{2}$ sodium tri-silicate turns into high-silica silicate $3\left(\alpha \mathrm{Na}_{2} \mathrm{O} \cdot 2 \mathrm{SiO}_{2}\right)+2 \mathrm{SiO}_{2}$, which at room temperature loses its ability to dissolve even in boiling water at atmospheric pressure, or it takes a long time to dissolve, or requires increased temperature and pressure of saturated water steam above it. Thus, maximum permissible heating temperature for SSSM, structured according to SMS-process, which ensures its destruction in water in technologically acceptable time, should be considered as: $t_{p}=600{ }^{\circ} \mathrm{C}$. Certain discrepancy between temperatures indicated above and those determined from dependence in Fig. 3 is explained by difference in research conditions and silicate modulus values used in SSS experiments.

Dependence of relative duration of destruction of mixture structured by SMS-process for 2 minutes in water on structured mixture with SSS 0.5 and $2.5 \%$ exposure (storing) duration in air and water temperature at 2 minutes mixture processing in steam-microwave environment, is shown in Fig. 5.

From dependencies in Fig. 5 it follows that relative duration of samples destruction in water (water resistance) increases with decrease in SSS mass used for cladding quartz sand, with decreasing water temperature in which sample was destroyed and with increasing duration of samples exposure in air

Relative time of dissolution (relative to dissolution time of mixture in water with temperature of 40 to $80{ }^{\circ} \mathrm{C}$ after 3-168 hours from the moment of the end of mixture within 2 minutes by the SMS-process structuring and without being heated (Fig. 5) can be calculated using empirical formula

$$
\nabla_{2}=\frac{240 \cdot \tau^{0.002 \cdot \tau}}{\left(0.1 \cdot t_{W}\right)^{3} \cdot m},
$$
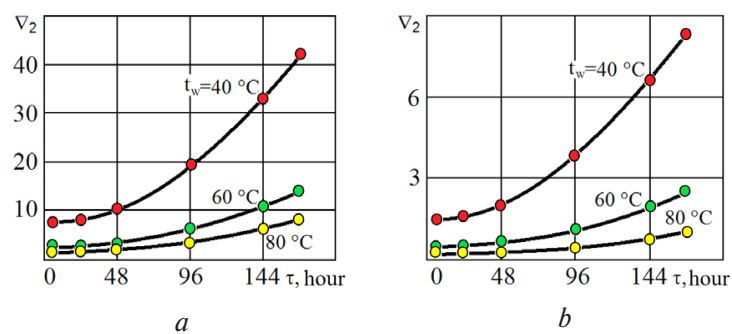

Fig. 5. Dependence of relative duration of destruction of structured mixture samples with 0.5 (a) and $2.5 \%$ (b) SSS in water on its air exposure duration and water temperature (SMS-process duration - 2 minutes) 
where $\mathrm{t}$ is structured mixture in air storing duration, hours; $t_{W}$ is water temperature during dissolution, ${ }^{\circ} \mathrm{C} ; m$ is SSS mass content in mixture, which was used for quartz sand cladding, $\%$ (over $100 \%$ of the sand).

Dependences of relative duration of destruction of structured mixture by SMS-process for 2 and 5 minutes in water on its temperature and the amount of SSS used for quartz sand cladding during initial mixture in steam-microwave environment processing, are shown in Fig. 6.

From analysis of course of the curves in Fig. 6 it follows that with water temperature increasing samples destruction duration (water resistance) decreases. It corresponds to known regularities of influence of solvent temperature on dissolved substance dissolution rate. In this case, if duration of mixture structuring with microwave radiation is 2 minutes, then mixture dissolution duration increases with decreasing SSS mass content, which was used for cladding quartz sand. If mixture structuring duration is 5 minutes, then mixture disintegration duration decreases with SSS mass content decreasing. That is, cladded sand with $2.5 \%$ SSS with SMS-process treatment for 5 minutes was sufficient for residual hydration water in sodium silicate content decreasing to value comparable to amount of residual water in sand cladded with $0.5 \%$ SSS cuffs. It follows from this that with certain duration of SMS-process, the nature of dependences on SMS-process duration and SSS used for sand cladding content should change to opposite.

These regularities are explained by simultaneous influence of two factors on water resistance $(\nabla)$ value - SSS amount used for quartz sand cladding and SMS-process duration during the period of its structuring. To explain these effects let us consider the cuffs schemes shown in Fig. 7.

Distinctive feature of the diagram in Fig. 7, $a$ compared to the diagram in Fig. 7, $b$ is cuff cross-section size. Naturally, with increase in SSS mass, spent on sand cladding, cuff cross section increases. At the same time, limited microwave radiation exposure duration during cladded sand structuring leads to the fact that part of hydration water remains in cuffs with a large cross section. This, in particular, is evidenced by dependence course shown in Fig. 8.

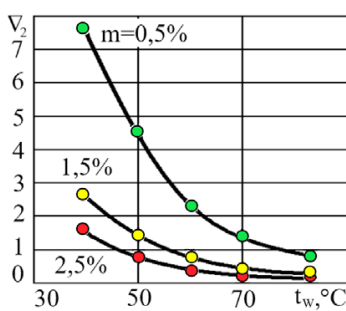

$a$

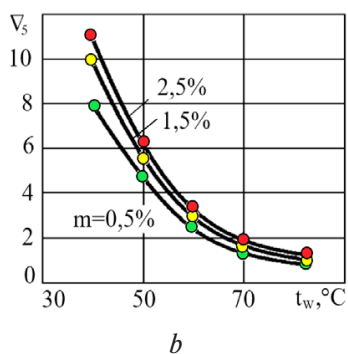

$b$
Fig. 6. Dependence of relative duration of destruction of mixture structured according to SMS-process during 2 (a) and 5 (b) minutes in water on water temperature and SSS amount used for cladding quartz sand when processing initial mixture in steam-microwave medium

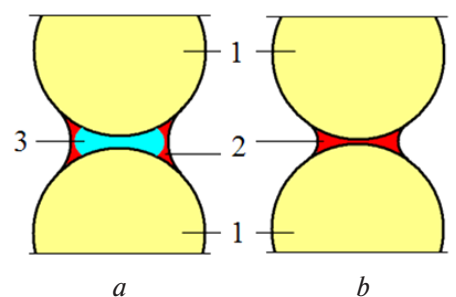

Fig. 7. Schemes of structured SSSM cuffs between sand grains cladded with 2.5 (a) and $0.5 \%$ (b) SSSM:

1 - sand grains; 2 - dehydrated sodium silicate; 3 - hydrated sodium silicate
From Fig. 8 it follows that after 2 minutes of microwave treatment in structured sand cladded with $0.5 \%$ SSS cuffs, water content decreases to $\sim 0.4 \%$. During the same time, in structured sand cladded with $2.5 \%$ SSS cuffs water content reduces to $\sim 11 \%$. It can be assumed that regardless of initial size, cuffs with bigger amount of hydrated water will dissolve in water at a faster rate than more dehydrated cuffs.

This assumption is confirmed by dependences of relative duration of destruction of structured mixture in water on initial mixture treatment according to SMS-process duration and SSS amount used for quartz sand cladding at water temperatures of 40 and $80{ }^{\circ} \mathrm{C}$, shown in Fig. 9 .

From analysis of dependence course in Fig. 9, it follows that, regardless of water temperature in which samples have been destroyed, nature of destruction relative duration (water resistance) from SSS used for sand cladding mass, changes with processing by SMS-process duration 3.1 minutes. That is, obtained regularities indirectly confirm the assumption about significant effect of structuring duration and, consequently, hydrated water content in SSS cuffs on their water resistance.

Conclusions. Sand-sodium-silicate mixture structured by SMS-process water resistance decreases with water temperature increasing and acquires an inversion character from its duration within 2-7 minutes and sodium silicate solute mass used for quartz sand cladding within $0.5-2.5 \%$ (over $100 \%$ of the sand). Inversion point corresponds to $\sim 3.1$ minutes of SMS-process duration. These peculiarities are due to residual (hydration) water amount in sodium silicate, which is located in structured mixture cuffs, size of cuffs themselves, which, in turn, depend on SSS consumed for cladding quartz sand mass.

With increasing duration of storing sand-sodium-silicate mixture structured by SMS-process in air, its water resistance increases, which is due to hydrated sodium silicate carbonization process in cuffs between grains of structured mixture.

Water resistance of sand-sodium-silicate mixture, structured according to SMS-process and preheated from 100 to $600{ }^{\circ} \mathrm{C}$, in boiling water monotonically increases with heating temperature increasing, sharply increases at temperatures from 600 to $700{ }^{\circ} \mathrm{C}$ and becomes almost absolute at higher

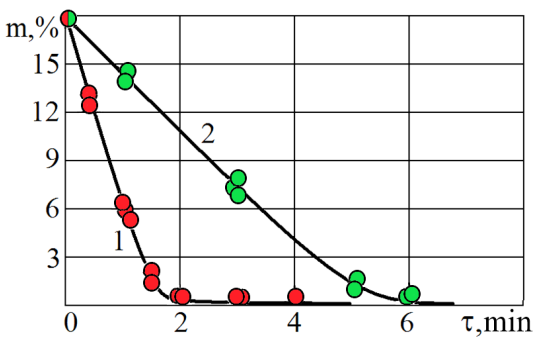

Fig. 8. Dependence of hydrated water content in SSSM cuffs as function of SMS-process duration ( $t$ ) with SSS mass used for cladding quartz sand 0.5 (1) and $2.5 \%$ (2) (over $100 \%$ sand)
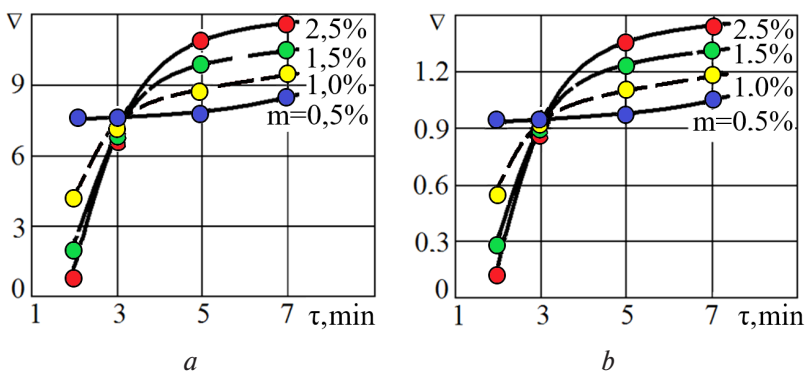

Fig. 9. Dependence of relative duration of destruction of structured mixture in water on initial mixture according to SMSprocess treatment time and SSS mass used for cladding quartz sand at water temperature $t_{W}=40{ }^{\circ} \mathrm{C}(\mathrm{a})$ and $t_{W}=80^{\circ} \mathrm{C}(\mathrm{b})$ 
temperatures. This regularity is due to decreasing residual (hydration) water amount in the structure of sodium silicate in mixture, with preheating temperature to $600{ }^{\circ} \mathrm{C}$ increasing, dehydration completing and structure of sodium silicate changing as a result of its preheating from 600 to $700{ }^{\circ} \mathrm{C}$, sodium silicate structure changing and sealing as a result of its melting when mixture is heated to temperatures above $700{ }^{\circ} \mathrm{C}$.

For extracting rods in water from sand-sodium-silicate mixture structured in steam-microwave environment and not heated to more than $600{ }^{\circ} \mathrm{C}$ the following is recommended:

- store rods in air for no more than 96 hours;

- after knocking out of the mold, immersing the casting in water when temperature on casting outer surface reaches 100 $200{ }^{\circ} \mathrm{C}$;

- using water temperature should be at least $40{ }^{\circ} \mathrm{C}$ for knockout by dissolution.

\section{References.}

1. Matvienko, A. V. (2019). The use of liquid glass. Science and education, 9(44), 41-42. Retrieved from https://cyberleninka.ru/article/n/ primenenie-zhidkogo-stekla/viewer.

2. Kravchenko, N.G., Kozlov, I. A., Shchekin, V. K., \& Efimov, E. A. (2021). Compositions of detergents for washing aircraft engines (review).VIAM Proceedings, 1(95), 105-113.https://doi.org/10.18577/23076046-2021-0-1-105-113.

3. Zin Min Khtet, \& Tikhomirova, I. N. (2017). Thermal insulation materials based on foamed liquid glass. Advances in chemistry and chemical technology, 3, 34-36. Retrieved from https://cyberleninka.ru/ article/n/teploizolyatsionnye-materialy-na-osnove-vspenennogozhidkogo-stekla/viewe.

4. Vladimirov, S. N., Ermakova, L. S., \& Partikeyev, I. A. (2016). A binder in the technology of briquetting solid household waste. Bulletin of Science and Practice, 5, 145-148. https://doi.org/10.18454/IRJ.2016.48.148. 5. Santana-Carrillo, J. L., Ortega-Zavala, D. E., Burciaga-Díaz, O., \& Escalante-Garcia, J. I. (2021). Modified blended limestone-Portland cement binders: Evaluation of 4 different sodium silicates. $\mathrm{Ce}$ ment and Concrete Composites, 118, 105-117. https://doi.org/10.1016/j. cemconcomp.2021.103935.

6. Loganina, V. I., \& Mazhitov, E. B. (2019). Regularities of the formation of the "sol-silicate-paint-substrate" adhesive contact. MGSU Bulletin, (1), 94-101. https://doi.org/10.22227/1997-0935.2019.1.94-101.

7. Igosheva, L.A., \& Grishina, A. S. (2016). Review of the main methods of strengthening soils with foundations. PNRPU Bulletin. Construction and architecture, (2), 5-21. https://doi.org/10.15593/2224-9826/2016.2.01.

8. Loganina, V. I., Kislitsyna, S. N., \& Mazhitov, Y. B. (2018). Development of sol-silicate composition for decoration of building walls. Case Studies in Construction Materials, (9), 1-4. https://doi. org/10.1016/j.cscm.2018.e00173.

9. Vadulina, N. V., Abdrakhmanov, N. Kh., Fedosov A. V., \& Badrtdinova, I. I. (2018). Development of a method for recycling waste from mining and processing plants by creating active filtering deironing materials. Bulletin of the Tomsk Polytechnic University. Engineering of georesources, 11, 37-43.

10. Guminsky, Yu.Yu., \& Rovin, S.L. (2019). Environmentally friendly liquid glass binder modified with ultrafine materials. Foundry, (3), 41-45. https://doi.org/10.21122 1683-6065-2019-3-41-45.

11. Solonenko, L. I., \& Rep'yakh, S. I. (2020). The taste of food-anddrink sums, which was structured with a steam-microchillo-type stump. Metallurgy and ore industry, (3), 39-47. https://doi.org/10.34185/05435749.2020-3-39-47.

12. Leushin, I. O., Koshelev, O. S., Maslov, K. A., \& Titov, A. V. (2020). Evaluation of the use of softening additives in the production of casting cores. Bulletin of the Magnitogorsk State Technical University. G. I. Nosov, (3), 25-33. https://doi.org/10.18503/1995-27-32-2020-18-3-25-33. 13. Krutilin, A. N., Guminsky, Yu. Yu., \& Rusevich, O. A. (2018). Improving the efficiency of using liquid glass mixtures. Part 3. Nanodispersed materials. Foundry, 3(92), 31-35. https://doi.org/10.21122/16836065-2018-92-3-31-35.

14. Mannanov, F. Kh. (2016). Evaluation of the environmental friendliness of foundry technology. Modern materials, equipment and technologies, 5(8), 130-135.

15. Lazarenkov, A. M. (2019). Air study of working areas of foundries. Casting and metallurgy, 2, 138-142. https://doi.org/10.21122/16836065-2019-2-138-142.

16. Illarionov, I. E., Strelnikov, I. A., \& Korolev, A. V. (2016). On the features of the use of metal phosphate mixtures. Foundry, 6, 5-7.
17. Petrova, N.V. (2016). Prospects for the use of metal phosphate binders for the production of casting molds and cores. Materials of the XIII final scientific and practical conference "Innovations in the educational process", 92-95. Retrieved from https://www.elibrary.ru/item.asp?id=37618604. 18. Solonenko, L. I., Usenko, R. V., Uzlov, K. I., Dziubina, A. V., \& Repiakh, S. I. (2020). Carbonization and crushability of structured sandsodium-silicate mixtures. Naukovyi Visnyk Natsionalnoho Hirnychoho Universytetu, (5), 40-46. https://doi.org/10.33271/nvngu/2020-5/040. 19. Solonenko, L. I., \& Repiakh, S. I. (2020). Ukrainian Patent No. 122538, Kyiv: State Patent Office of Ukraine.

20. Bondarenko, V., Svietkina, O., Sai, K., \& Klymenko, V. (2018). Investigation of the influence of polyelectrolytes hydrodynamic properties on the hydrateformation process. E3S Web of Conferences, 60, 00007. https://doi.org/10.1051/e3sconf/20186000007.

\section{Водостійкість структурованих піщано- рідкоскляних сумішей}

\section{Л. I. Солоненко ${ }^{1}$, С. I. Pen'ях ${ }^{2}$, К. I. Узлов ${ }^{2}$, I. Мамузич ${ }^{3}$ О. П. Білий', Т. В. Кімстач ${ }^{2}$}

1 - Державний університет «Одеська політехніка», м. Одеса, Україна

2 - Національна металургійна академія України, м. Дніпро, Україна, e-mail: 123rs@ua.fm

3 - Загребський університет, Хорватське металургійне товариство, м. Загреб, Республіка Хорватія

Мета. Встановити закономірності зміни відносної водостійкості піщано-рідкоскляних сумішей (ПРС), структурованих методом паро-мікрохвильового затвердіння (ПМЗ), від параметрів їх структурування та умов розчинення рідкого скла (РС).

Методика. У роботі використовували воду технічної чистоти, РС із силікатним модулем 2,8-3,0, кварцовий пісок із середнім розміром частинок 0,23 мм. Дослідження проводили на зразках із кварцового піску, що попередньо був плакований $0,5-2,5 \%$ (за масою), РС і структурований методом ПМЗ. Час руйнування структурованих сумішей оцінювали на зразках кубічної форми з довжиною ребра 20 мм, занурених у воду за різних температур.

Результати. Встановлені закономірності зміни водостійкості ПРС у воді в залежності від умов їх виготовлення, використання та зберігання. Розроблені рекомендації з видалення піщано-рідкоскляних стрижнів із виливків у воді.

Наукова новизна. Уперше встановлено, що відносна водостійкість ПРС, що структурована методом ПМЗ, зменшується зі збільшенням температури води, в якій вона руйнується. У той же час, у залежності від маси РС, що використали для плакування кварцового піску в діапазоні від 0,5 до 2,5\%, залежність водостійкості від обробки в паро-мікрохвильовому середовищі тривалістю від 2 до 7 хвилин набуває інверсійний характер з точкою інверсії на $\sim 3,1$ хвилині обробки. Уперше встановлено, що в киплячій воді у ПРС, що була структурована за ПМЗ-процесом і пройшла попередній нагрів, відносна водостійкість монотонно зростає при підвищенні температури попереднього нагрівання від 100 до $600^{\circ} \mathrm{C}$, а при нагріванні до $600-700^{\circ} \mathrm{C}$ різко зростає і практично стає абсолютною після попереднього нагріву до більш високих температур.

Практична значимість. Результати досліджень будуть корисні в частині розширення уявлень про процеси, шо супроводжують руйнування структурованих пісків з водорозчинними сполучними матеріалами, а також при розробці технологій та обладнання, призначених для видалення рідкоскляних стрижнів і залишків ливарних форм із виливків.

Ключові слова: водостійкість, рідке скло, піщано-рідкоскляна суміш, вибивка, паро-мікрохвильове затвердіння, стрижень

Recommended for publication by V. Seliviorstov, Doctor of Technical Sciences. The manuscript was submitted 04.02.21. 